\title{
Enlargement of the caecum in the rat in iron deficiency
}

\author{
By M. G. McCALL, G. E. NEWMAN and L. S. VALBERG* \\ Nuffield Department of Clinical Medicine and \\ Nuffield Department of Clinical Biochemistry, The Radcliffe Infirmary, Oxford
}

(Received I I October 1961-Revised 6 February 1962)

It is known that the composition of a rat's diet may affect the size of its caecum. Wierda (1942) observed that the length of the caecum was increased in animals fed on a diet supplemented with $10-30 \%$ agar, compared to animals on similar but unsupplemented diets. The caecums were larger in rats fed on a diet supplemented with dextrinized maize starch than in animals fed on a similar diet supplemented with sucrose (Johansson \& Sarles, 1949). Fischer (1957) found an increase in the absolute and relative caecal weights in rats fed on diets containing $25 \%$ lactose, agar or raw potato starch or $10 \%$ arabinose, but not with $25 \%$ wood cellulose, compared with control animals given maize starch as their only carbohydrate. Moinuddin \& Lee (1959) made similar observations. In the course of work with a semi-synthetic diet used for the experimental production of iron deficiency in rats, caecal enlargement was observed (Taylor \& Witts, 1958; Valberg, Taylor, Witts \& Richards, I96r). We report here an investigation of the relationship of diet, and of $\mathrm{Fe}$ deficiency, with the size of the rat's caecum.

\section{EXPERIMENTAL}

\section{Materials and methods}

Female weanling albino rats, derived from Wistar strain stock, were obtained from the War Department, Allington Farm, Porton Down, Salisbury, and housed in Perspex cages with wide-mesh aluminium floors, as described elsewhere (McCall, Newman, O'Brien, Valberg \& Witts, 1962). Two basic diets were used, a standard rat-cake diet (modified diet 4I B based on diet 4I of Bruce \& Parkes, I 949 and Bruce, I950) supplied by Oxo Ltd, Thames House, London, E.C. 4, and a semi-synthetic Fe-deficient diet. The rat cake was compounded of wheatmeal flour 46, Sussexground oats 40 , white-fish meal 8 , dried skim milk 3 , dried yeast I, mineral supplement I and a vitamin supplement $\mathrm{I} \%$; analysis of this diet showed an $\mathrm{Fe}$ content of $95 \mathrm{mg} / \mathrm{kg}$. The semi-synthetic diet has been described in detail elsewhere (diet I of McCall et al. 1962). It contained $\mathrm{I}-3 \mathrm{mg} \mathrm{Fe} / \mathrm{kg}$ and consisted of spray-dried skimmilk powder 65 , sucrose 20, fat mixture (lard and arachis oil, 3:I by weight) ro, vitamin and mineral supplements $5 \%$. The Fe-supplemented diet differed only in the addition of $\left(\mathrm{NH}_{4}\right)_{2} \mathrm{SO}_{4} \cdot \mathrm{FeSO}_{4} \cdot 6 \mathrm{H}_{2} \mathrm{O}$ to give $240 \mathrm{mg} \mathrm{Fe} / \mathrm{kg}$ diet.

The rats were weighed on a direct-reading Mettler balance (Type $\mathrm{K}_{4}$ ) once a week,

* Present address: Department of Medicine, Etherington Hall, Queen's University, Kingston, Ontario, Canada. 
and just before slaughter. Duplicate weighings were within $2 \mathrm{~g}$. The volume of the caecum was measured by its displacement of water in a graduated cylinder. The blood haemoglobin concentration was determined in a sample from a tail vein, as described elsewhere (McCall et al. I962). Imferon was obtained from Benger Laboratories Ltd and is an 'iron dextran complex'. Micropaque was obtained from Damancy and Co. Ltd, and cellulose powder (Whatman's standard grade) from W. and R. Balston Ltd.

\section{Experiment I}

Expt I was divided into two parts, in order to establish the effect of different diets and their Fe content on the size of the caecum and then to study the effect of changing from one diet to another. In the first part of this experiment ninety weanling rats were divided into five equal groups, with litter-mates represented equally in each, and each group was fed ad lib. on one of the diets: rat cake; Fe-deficient semi-synthetic; Fe-supplemented semi-synthetic; Fe-deficient semi-synthetic with 10 \% cellulose; Fe-supplemented semi-synthetic with $10 \%$ cellulose. After 42 days on these diets six rats from each group were weighed and killed, and their blood haemoglobin concentrations and caecal volumes were measured.

In the second part of this experiment the remaining twelve rats previously fed on the Fe-deficient diet were divided into three equal groups, one remaining on the same diet, the others being changed to the Fe-supplemented diet or rat cake for $3^{2}$ days. The twelve rats fed on the Fe-supplemented diet were treated in a similar fashion, four continuing on their original diet, the other two groups of four each being changed to the $\mathrm{Fe}$-deficient or rat-cake diets for 32 days. At the end of this time these rats were weighed, killed, and their blood haemoglobin concentration and caecal volumes were measured.

\section{Experiment 2}

In this experiment, a study was made of the effect of Fe given parenterally on the enlargement of the caecum in rats fed on an Fe-deficient diet. Eighteen weanling rats were divided into three equal groups with litter-mates represented equally in each. Two of the groups were fed on the Fe-deficient diet, and at the beginning of the experiment each animal in one of these groups received $20 \mathrm{mg} \mathrm{Fe}$ (as Imferon) by intramuscular injection. The third group was fed on the Fe-supplemented diet and did not receive $\mathrm{Fe}$ parenterally. The diets were given ad lib. for 42 days, the rats were then weighed and killed, and their blood haemoglobin concentrations and caecal volumes were measured. During this experiment caecal function was studied by giving Micropaque by stomach tube to rats on Fe-deficient and Fe-supplemented diets and following the passage of the radio-opaque material with serial radiographs. The bacterial flora of the caecums of the six rats fed on the Fe-supplemented diet and the six rats fed on the Fe-deficient diet and not receiving Fe parenterally was studied.

\section{RESULTS}

A transitory diarrhoea with frequent watery stools was observed in all animals transferred to any of the semi-synthetic diets used. 


\section{Experiment I}

The results of the first part of this experiment are shown in Table I and Pl. I. The body-weights of rats fed on the rat-cake or on the semi-synthetic Fe-supplemented diets were similar and tended to be larger than those of animals receiving the Fedeficient diets. Addition of cellulose to the semi-synthetic diets appeared to affect growth adversely.

Table I. Effect of diet on the size of the rat's caecum

\begin{tabular}{|c|c|c|c|c|c|}
\hline \multirow[b]{2}{*}{$\begin{array}{l}\text { No. } \\
\text { of } \\
\text { rats }\end{array}$} & & \multirow[b]{2}{*}{$\begin{array}{l}\text { Mean } \\
\text { body- } \\
\text { weight } \\
(\mathrm{g})\end{array}$} & \multirow[b]{2}{*}{$\begin{array}{l}\text { Mean } \\
\text { blood } \\
\text { haemo- } \\
\text { globin } \\
(\mathrm{g} / \mathrm{r} \text { rooml })\end{array}$} & \multicolumn{2}{|c|}{ Size of caecum } \\
\hline & Diet & & & $\begin{array}{l}\text { Volume* } \\
(\mathrm{ml})\end{array}$ & $\begin{array}{c}\text { As } \\
\text { percentage } \\
\text { of body- } \\
\text { weight* }\end{array}$ \\
\hline 6 & Rat cake & 122 & $15 \cdot 3$ & $2 \cdot 0 \pm 0.1$ & $I \cdot 6 \pm 0 \cdot I$ \\
\hline 6 & Fe-deficient & I I I & $8 \cdot 0$ & $8 \cdot 0 \pm 0.6$ & $7 \cdot 2 \pm 0.8$ \\
\hline 6 & Fe-deficient plus 10 $\%$ cellulose & 97 & $8 \cdot 5$ & $7.8 \pm 0.8$ & $8 \cdot 0 \pm 0 \cdot 7$ \\
\hline 6 & Fe-supplemented & I 30 & $16 \cdot 4$ & $4.5 \pm 0.2$ & $3.5 \pm 0.2$ \\
\hline 6 & Fe-supplemented plus 10\% cellulose & 120 & I $5 \cdot 9$ & $4.0 \pm 0.2$ & $3 \cdot 3 \pm 0.2$ \\
\hline
\end{tabular}

* Mean value with standard deviation.

Table 2. Effect of changing or continuing the diet on the size of the caecum enlarged in rats by eating an Fe-deficient semi-synthetic diet

\begin{tabular}{|c|c|c|c|c|c|c|}
\hline \multirow[b]{2}{*}{$\begin{array}{l}\text { No. } \\
\text { of } \\
\text { rats }\end{array}$} & \multirow[b]{2}{*}{ Diet } & \multirow[b]{2}{*}{$\begin{array}{c}\text { Days } \\
\text { after } \\
\text { change } \\
\text { of } \\
\text { diet }\end{array}$} & \multirow[b]{2}{*}{$\begin{array}{l}\text { Mean } \\
\text { body- } \\
\text { weight } \\
(\mathrm{g})\end{array}$} & \multirow{2}{*}{$\begin{array}{c}\text { Mean } \\
\text { blood } \\
\text { haemo- } \\
\text { globin } \\
\text { concen- } \\
\text { tration } \\
(\mathrm{g} / \text { Iooml) }\end{array}$} & \multicolumn{2}{|c|}{ Size of caecum } \\
\hline & & & & & $\begin{array}{l}\text { Volume* } \\
\text { (ml) }\end{array}$ & $\begin{array}{c}\text { As } \\
\text { percentage } \\
\text { of body- } \\
\text { weight* }\end{array}$ \\
\hline 6 & Fe-deficient & ○ & I I I & $8 \cdot 0$ & $8 \cdot 0 \pm 0.6$ & $7 \cdot 2 \pm 0.8$ \\
\hline 4 & Fe-deficient & 32 & 153 & $6 \cdot 5$ & $13.5 \pm 0.6$ & $8.8 \pm 0.8$ \\
\hline 4 & Fe-supplemented & 32 & 159 & $17 \cdot 0$ & $5 \cdot 4 \pm 0.6$ & $3 \cdot 4 \pm 0.3$ \\
\hline 4 & Rat cake & 32 & 152 & I5. I & $3.2 \pm 0.1$ & $2 \cdot 1 \pm 0.1$ \\
\hline
\end{tabular}

The final haemoglobin concentrations of rats fed on the rat-cake and on the Fe-supplemented diets were similar. Animals fed on the Fe-deficient diets were, by comparison, anaemic. The addition of cellulose to the diets did not appear to affect the haemoglobin levels in these animals.

Rats reared on the rat cake had caecums half the size, relative to body-weight, of the caecums of rats fed on the Fe-supplemented semi-synthetic diet. The caecums of rats fed on the Fe-deficient diets were largest, being twice the size, relative to body-weight, of those of animals on a similar diet supplemented with Fe. The addition of cellulose to either the Fe-deficient or the Fe-supplemented diet was without effect on caecal size.

Results of the second part of the experiment are shown in Tables 2 and 3 . The findings in those rats killed before the change of diet are included at the top of each 
table. Animals changed from an Fe-deficient to an Fe-supplemented diet increased their haemoglobin levels to those of Fe sufficiency within $3^{2}$ days. Animals changed from the Fe-supplemented to the Fe-deficient diet did not become anaemic in the same length of time. Changing the diet of animals initially fed on the Fe-deficient semi-synthetic diet resulted in a diminution of caecal size, most pronounced in those rats transferred to the rat cake. In 32 days the caecums of animals changed from the Fe-supplemented diet to the rat cake became smaller, whereas in animals changed to the Fe-deficient diet they became larger in proportion to body-weight. The latter change occurred in the absence of anaemia.

Table 3. Effect of changing or continuing the diet on the size of caecum enlarged in rats by eating an Fe-supplemented semi-synthetic diet

\begin{tabular}{|c|c|c|c|c|c|c|}
\hline \multirow[b]{2}{*}{$\begin{array}{l}\text { No. } \\
\text { of } \\
\text { rats }\end{array}$} & \multirow[b]{2}{*}{ Diet } & \multirow[b]{2}{*}{$\begin{array}{c}\text { Days } \\
\text { after } \\
\text { change } \\
\text { of } \\
\text { diet }\end{array}$} & \multirow[b]{2}{*}{$\begin{array}{c}\text { Mean } \\
\text { body- } \\
\text { weight } \\
\text { (g) }\end{array}$} & \multirow{2}{*}{$\begin{array}{c}\text { Mean } \\
\text { blood } \\
\text { haemo- } \\
\text { globin } \\
\text { concen- } \\
\text { tration } \\
(\mathrm{g} / 100 \mathrm{ml})\end{array}$} & \multicolumn{2}{|c|}{ Size of caecum } \\
\hline & & & & & $\begin{array}{l}\text { Volume* } \\
\text { (ml) }\end{array}$ & $\begin{array}{c}\text { As } \\
\text { percentage } \\
\text { of body- } \\
\text { weight* }\end{array}$ \\
\hline 6 & Fe-supplemented & 0 & 130 & I6.4 & $4.5 \pm 0.2$ & $3.5 \pm 0.2$ \\
\hline 4 & Fe-supplemented & 32 & 164 & $16 \cdot 3$ & $5 \cdot 4 \pm 0.6$ & $3 \cdot 3 \pm 0.6$ \\
\hline 4 & Fe-deficient & 32 & ${ }_{15} \mathrm{I}$ & 15.0 & $8.0 \pm 0.1$ & $5.3 \pm 0.2$ \\
\hline 4 & Rat cake & 32 & 184 & $16 \cdot 0$ & $3.5 \pm 0.2$ & $1.9 \pm 0.1$ \\
\hline
\end{tabular}

Table 4. Effect of parenteral injection of iron on the size of the caecum of rats fed on an Fe-deficient semi-synthetic diet

\begin{tabular}{|c|c|c|c|c|c|}
\hline \multirow[b]{2}{*}{$\begin{array}{l}\text { No. } \\
\text { of } \\
\text { rats }\end{array}$} & \multirow[b]{2}{*}{ Diet } & \multirow[b]{2}{*}{$\begin{array}{c}\text { Mean } \\
\text { body- } \\
\text { weight } \\
\text { (g) }\end{array}$} & \multirow{2}{*}{$\begin{array}{c}\text { Mean } \\
\text { blood } \\
\text { haemo- } \\
\text { globin } \\
\text { concen- } \\
\text { tration } \\
\text { (g/rooml) }\end{array}$} & \multicolumn{2}{|c|}{ Size of caecum } \\
\hline & & & & $\begin{array}{l}\text { Volume* } \\
\text { (ml) }\end{array}$ & $\begin{array}{c}\text { As } \\
\text { percentage } \\
\text { of body- } \\
\text { weight* }\end{array}$ \\
\hline 6 & Fe-supplemented & 122 & $18 \cdot 0$ & $5 \cdot 3 \pm 0 \cdot 2$ & $4 \cdot 4 \pm 0 \cdot 1$ \\
\hline 6 & Fe-deficient & 108 & $8 \cdot 6$ & $7.6 \pm 0.5$ & $7 \cdot 2 \pm 0 \cdot 5$ \\
\hline 6 & $\begin{array}{l}\text { Fe-deficient, injection of } \\
\text { Imferon }\end{array}$ & I33 & $16 \cdot 0$ & $7 \cdot 3 \pm 0 \cdot 6$ & $5.5 \pm 0.5$ \\
\hline
\end{tabular}

\section{Experiment 2}

The results are shown in Table 4 . The effects on body-weight, haemoglobin concentration and caecal size of Fe-supplemented and Fe-deficient semi-synthetic diets were similar to those described in Expt I. The effect of Fe given parenterally to animals fed on the Fe-deficient diet was to enhance their growth and to prevent the development of anaemia. In these animals the absolute caecal size was similar to that of litter-mates fed on the Fe-deficient diet. Relative to body-weight however, their caecal size was in between that of the animals on Fe-supplemented and Fe-deficient diets (Table 4 ). 
Preliminary experiments showed the presence of lactobacilli, coliforms and Staphylococcus albus in the caecums of animals given the Fe-supplemented diet, whereas in animals given the Fe-deficient diet Streptococcus faecalis and Proteus mirabilis were found more frequently.

Studies with Micropaque revealed no difference in transit time through the gastrointestinal tract of rats on the Fe-deficient or Fe-supplemented diets. Although the caecum was larger in the Fe-deficient rats it was capable of contraction and it appeared to function normally in the formation of faecal pellets.

\section{DISCUSSION}

Though caecal enlargement has been described in rats on a variety of diets (Wierda, 1942; Fischer, 1957; Moinuddin \& Lee, 1959; and others), there is no satisfactory explanation. It does not appear to matter whether the caecum is measured as its dry weight, volume or surface area, for all these measurements are directly related in the rat (Moinuddin \& Lee, 1959).

Caecal size does not appear to be related to the quantity of faecal residue (Moinuddin \& Lee, I959); in the studies described here the faecal residue of animals fed on the rat cake was several times that of animals on the semi-synthetic diets. It is probable that the caecal enlargement of rats confined to the semi-synthetic diets occurred because of the high lactose content of these diets (about $25 \%$ ), due to the milk-powder base (Moinuddin \& Lee, 1959), but there is no evidence to suggest why the change should be more pronounced in the rats on the Fe-deficient diet.

The attempt to separate the possible effect on caecal enlargement of tissue $\mathrm{Fe}$ deficiency from that of the low intestinal $\mathrm{Fe}$ content was inconclusive. Though the size of the caecum relative to body-weight increased in rats fed on an Fe-deficient diet but protected against tissue Fe deficiency by injected $\mathrm{Fe}$, their caecums were nevertheless smaller than those of Fe-deficient animals.

Experiments have shown that the enlargement of the caecum occurs within ro days of transfer from the rat cake to a semi-synthetic diet (McCall, I96r). The experiments described here demonstrate the reversibility of this change within 32 days after a return from a semi-synthetic diet to the rat cake.

Changes in the bacterial flora have been postulated as a cause of caecal enlargement. Lee \& Moinuddin (1958) found caecal enlargement in rats given tetracycline by mouth, and enlargement of the caecum has been described in germ-free animals (Reyniers, 1956). Since inorganic $\mathrm{Fe}$ is required for bacterial growth, the caecal contents from six rats given Fe supplements and six Fe-deficient rats were examined. Preliminary results showed no striking bacteriological differences.

Moinuddin \& Lee ( 1959 ) postulated that the increase in caecal size might be due to increased work in abstracting water from its contents against osmotic forces. It is possible that the transitory diarrhoea, lasting for about 7 days, observed in these studies and by Lee \& Moinuddin (1958) to occur in rats immediately after their transfer to a diet producing caecal enlargement, represents the initial failure of water absorption on the new diet, before a compensatory caecal enlargement. 


\section{SUMMARY}

I. In experiments in which a semi-synthetic diet was used for the experimental production of iron deficiency in rats, enlargement of the caecum was observed and this change was studied further.

2. The caecums of rats fed on a semi-synthetic diet, containing a large proportion of lactose, were larger than those of animals fed on a commercial rat-cake diet.

3. In rats confined to semi-synthetic diets, those receiving an Fe-deficient diet had larger caecums than those receiving an Fe-supplemented diet.

4. The enlargement of the caecum diminished when rats were transferred from a semi-synthetic Fe-deficient diet to a semi-synthetic Fe-supplemented diet, or from either of these diets to the rat cake.

5. Though the size of the caecum relative to body-weight increased in rats fed on an Fe-deficient diet but protected against tissue Fe deficiency by injected $\mathrm{Fe}$, their caecums were smaller than those of Fe-deficient rats.

We gratefully acknowledge the advice and helpful criticisms of Mr J. R. P. O'Brien and Professor L. J. Witts. We wish also to thank Dr P. W. Griffiths of the Department of Bacteriology for the bacteriological studies and Mr J. Halfacree for his technical assistance. The work was supported in part by a Medical Research Council grant to Professor L. J. Witts.

\section{REFERENCES}

Bruce, H. M. (1950). F. Hyg., Camb., 48, I 71.

Bruce, H. M. \& Parkes, A. S. (1949). $\mathscr{~}$. Hyg., Camb., 47, 202.

Fischer, J. E. (1957). Amer. F. Physiol. 188, 550.

Johansson, K. R. \& Sarles, W. B. (1949). Bact. Rev. 13, 25.

Lee, H. W. 'T. \& Moinuddin, J. F. (1958). Amer. F. Physiol. 192, 421.

McCall, M. G. (I96I). Study of experimental iron deficiency. D.Phil Thesis, University of Oxford. McCall, M. G., Newman, G. E., O'Brien, J. R. P., Valberg, L. S. \& Witts, L. J. (1962). Brit. F. Nutr. I6, 297

Moinuddin, J. F. \& Lee, H. W. T. (1959). Amer. F. Physiol. 197, 903.

Reyniers, J. A. (1956). Proc. int. Congr. Biochem. III. Brussels, p. $45^{8}$.

Taylor, K. B. \& Witts, L. J. (I958). Quart. F. Med. 27, 565.

Valberg, L. S., Taylor, K. B., Witts, L. J. \& Richards, D. (r96r). Brit. F. Nutr. 15, 473.

Wierda, J. L. (I942). Amer. $\mathscr{~}$. Anat. 7o, 433.

EXPLANATION OF PLATE

Enlargement of the caecum in the rat; left to right, the abdominal contents of three litter-mates receiving the rat-cake, the Fe-supplemented semi-synthetic and the Fe-deficient semi-synthetic diets respectively. 
British Gournal of Nutrition, Vol. I6, No. 3

Plate I

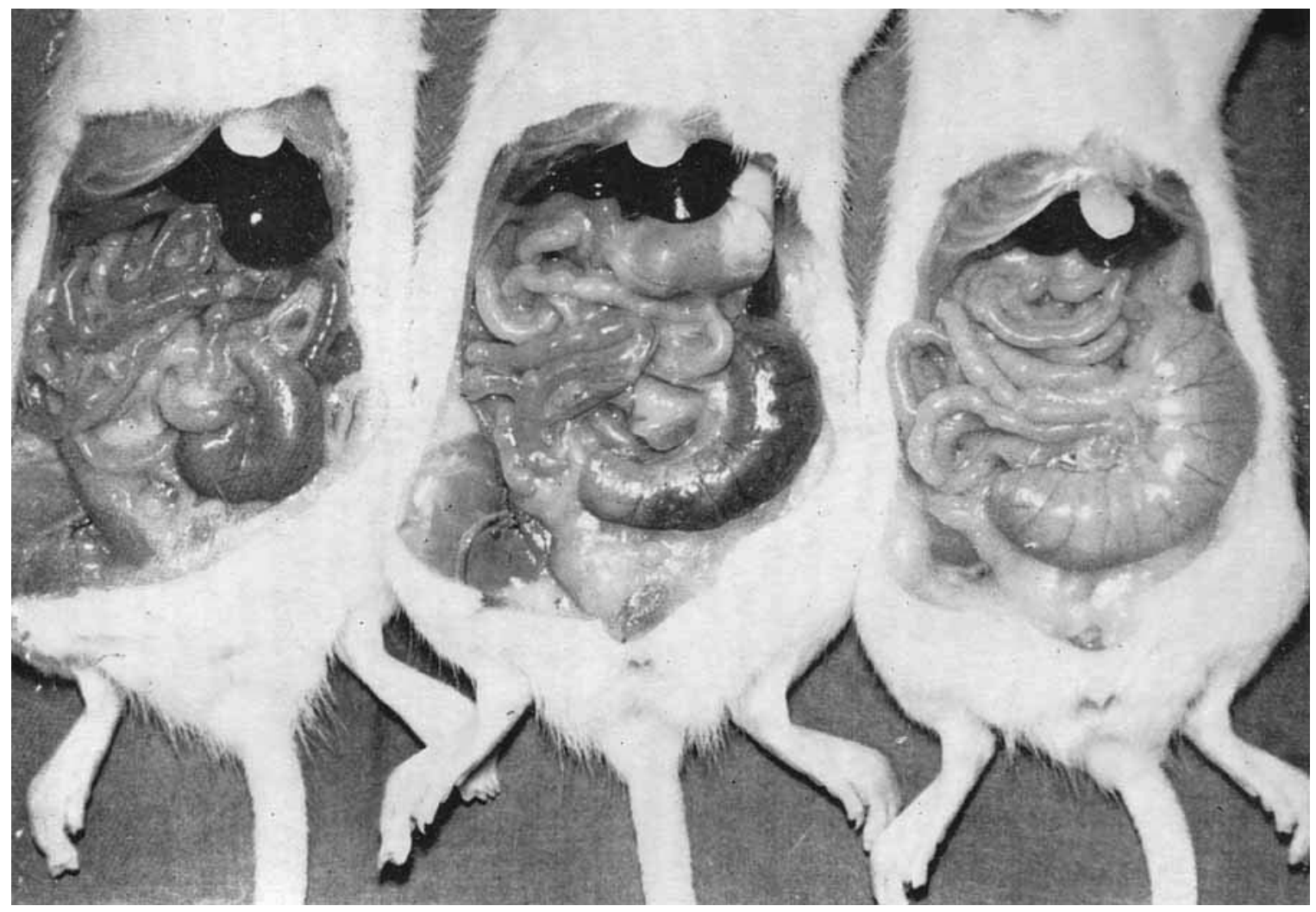

